\title{
The Moderating Effects of Dividend Policy on the Impact of Financial Disclosure Towards Corporate Value: A Study of Listed Jordanian Industrial Firms
}

\author{
Yousef Shahwan \\ Assistant professor Department of accounting, Zarqa University, Jordan
}

\begin{abstract}
This study is primarily designed to examine the moderating effects of dividend policy on the impact of financial statement disclosure towards the corporate value of the Jordanian industrial companies listed in Amman Stock Exchange (ASE). In this study, the unit of analysis consist of 61 industrial firms, which is equivalent to $63 \%$ of the total number of Jordanian listed industries in ASE as at 2011. Therefore, secondary data was used, in which the data was collected from the annual financial reports disclosed by the selected industrial firms covering the period of 13 years from 2005 to 2017. Analysis was made through SPSS version 21 and SmartPLS version 3. Accordingly, findings of this study revealed that the total direct effects between the variables were positively significant at $\mathrm{p}$-value $<0.001$ whereas, the moderating effects of dividend policy was proved to be insignificant at $p$-value $>0.05$. Moreover, the total contribution of the exogenous variables in the prediction of endogenous variable is $85 \%$. Based on the findings, it is recommended that, Jordanian listed industrial firms should consider a full disclosure of their financial transaction since accountability and transparency attracts potential investors and creditors alike to pick interest in doing business with utmost financial security. It is recommended that the listed industrial firms of Jordanian should be given a maximum consideration to the indicators used in this study since the indicators were perfects to measure the variables under study for a better management decisions.
\end{abstract}

Keywords: Dividend policy, Financial Disclosure, Corporate Value, Management Decisions

DOI: $10.7176 /$ RJFA/10-6-13

Publication date:March $31^{\text {st }} 2019$

\subsection{Introduction}

In the present day, financial disclosure is one of the key facets of accounting that is playing an unimaginable role among various categories of financial information users. These users include both internal (shareholders, employees, managers, board of directors etc) and external (investors, government, customers, and general public) to whom the financial information is communicated in order to draw a sound investment and other financial decisions (Wild, Shaw \& Chiappetta, 2009). As such, financial disclosure reveals a true and fair view of the financial position of a given organization when fully complied with statutory regulations of financial disclosure such as IAS, IFRS and GAAP among others. Corporate financial disclosure, precisely annual financial reports, serve as one of the most important communication tool which proved both financial and non-financial information about a firm (Barako, 2007). In a general terms, the disclosed financial information may equipped the users with sufficient information, skills and techniques to compute, analyse and interpret the information so as to understand the financial strength and weaknesses of the organization for them to make a sound and effective decision. Therefore, among other advantages of financial disclosure is to ensure proper dissemination of reliable information to the entire stakeholders regarding firm's value which prevent the managers and directors from cheating them out of their investments (Bushman \& Smith, 2003) and led to maximization of corporate value rather than personal interest (Black, 2000).

Maximization of the shareholders' wealth is one of the primary concerns to the managers which is regarded as the pre-requisite economic objective to be achieved in the organization. Accordingly, this objective can only be realized through proper distribution of the adequate financial resources. Worthington \& Tracey (2004) opined that, managers of the business organization may prioritise the objective of maximizing the shareholders' value as their main goal through which the targeted economic objective of the organization could be achieved. As such, they continue to state that this goal can be attained by replacing the shareholders' value with financial statement ratio, profit or cash flow. Therefore, the stakeholders of firms and other interested parties may use the financial reports disclosed to forecast the firm performances which includes the ability of a firm to pay higher return to the shareholders (dividend).

Usually, financial statement used to discloses vital information to the organizational stakeholders especially investors and managers. This financial information include dividend per share, earning per share, total assets and total liabilities among others (Mmbone, Hood \&Wambui, 2015).). Accordingly, from the disclosed financial information the managers may have a perfect hint towards formulating a sound and effective dividend policy which will in turn attract the interest of potential investors to invest as well as the existing ones to re-invest. Thus, this study staunched to evaluate the moderating effects of dividend policy on the impacts of financial disclosure 
against the corporate value in the Jordanian industrial companies listed in ASE. The study was made of four sections, whereas section one displayed an abstract and introduction, section two discusses literature review and hypotheses development, in section three a methodology of the study was presented and lastly, section four conversed the data presentation, hypotheses test and discussion of findings and recommendation.

\subsection{Statement of the Research Problem}

Considering the fundamental role playing by the financial disclosure, exclusively published annual reports, which communicate financial and non-financial information to the potential and existing investors in Jordan specifically about the activities of the listed companies in ASE. Usually, these reports are made available, free and accessible to the general public, which in turn attract both foreign and domestic potential investors to pick interest in a particular firm after analysing and considering various components of the obtained reports. In many decades, researchers in Jordan and outside Jordan have developed much interest in the finding out the effects of financial disclosure on the firm value/performance (for example, Mmbone, et, al., 2015; Kristandle \& Bontis, 2007; Leuz \&Verrechia, 2000; Ross, 1997; Wallace \& Naser,1995; Hossain, Perera \& Rahman, 1995) or the effects of dividend policy on the corporate performance (see, Kajola, Adewumi, \& Oworu, 2015; Dogan \& Topal, 2014; Maniagi, Denco, Ondiek, Okaka, \& Musiega, 2013; Murekefu, \& Ouma, 2012; Barclay, Holderness, \& Sheehan, 2009). Therefore,in the case of Jordan, a large number of researchers have concentrated on either the effects of corporate governance on dividend policy (see, Yaseen, Omet \& Abu Khalf, 2015; Mohammad, Taher \& Jamil, 2011; Al-Habaybah, 2009) or an impacts of voluntary disclosure on dividend or corporate performance (example, Ailwan, Katrib \& Samara, 2013; Khaled, 2012).

Despite the crucial role of both dividend policy and financial disclosure in relation to the corporate value, particularly in the Jordanian industrial firms, yet there is limited research conducted in Jordan covering the moderating effects of dividend policy on the financial disclosure against corporate value in the Jordanian industrial companies. Consequently, this study is coxswained to address the one million dollar question as do dividend policy moderate the effect of financial disclosure on the corporate value of manufacturing industries listed ASE?

\subsection{Research Objectives}

The primary objective of this study is to examine the moderating effects of dividend policy on financial disclosure against corporate value in the listed industrial firms in Jordan. Hence, specific objectives were illustrated as follow:

i. To examine the effects of dividend policy on the corporate value in the Jordanian listed industrial firms.

ii. To evaluate the extent at which the dividend policy significantly affects the corporate value in the listed Jordanian industrial companies.

iii. To study the related impacts of financial disclosure on the corporate value in the Jordanian listed industrial firms.

\subsection{Literature Review and Hypotheses Development}

Over the decades, many researchers have conducted a series of studies towards establishing the impacts of financial disclosure and dividend policy on the corporate value. Ailwan, et. Al., (2013) have revealed in their empirical study that a financial statement that compliance with financial reporting standards discloses the true and fair view of the companies' financial position which at the end attract the interest of investors and resulted to an increase in profits. Insufficient financial disclosure was one of the key factors that led to the voluntary disclosure due to the excessive pressure put forth by the investors and shareholders alike, where they demand accountability and transparency related to the corporate performances and long term strategies (Boesso \& Kumar, 2007). However, when it comes to the issue of the impacts of dividend policy in relation to the corporate value, the argument was based on the two recognised scenarios. In the first place, the findings of M\&M theory of irrelevance coined in 1961 which portrayed dividend policy as irrelevant towards determining the value of firms. Hence, their findings were supported by the works of many scholars (for example, Efni, 2017; Black, 1976). Contrarily, it has been proved in some previous studies that dividend policy is an important determinant of corporate values (see the works of Al-Kuwari, 2009; Gordon, 1959; Lintner, 1956). Recently, numerous definitions have described dividend policy as a key factor that led to an increase in the organizational profit (Marsh, 2012; Ehrhardt, 2012; Abiola, 2001; Aduda \& Kimathi, 2011). In their empirical study Kajola, Adewumi \& Oworu (2015) have found a significant and positive relationship between the dividend policy and corporate value. Accordingly, in their study, dividend payout ratio was used to measure the dividend policy which was the dependent variable and return on assets was used to measure the independent variable which was the corporate performance as well as control variable was employed in the form of profitability.

In addition, Efni (2017) investigated the mediating effects of investment decision and financing decisions on the effects of corporate risk and dividend policy against corporate value. She used secondary data, which was 
collected from the 9 years published annual financial reports of the selected listed Indonesian real sector companies and SmartPls was used to regress the relationship path between the variables under study. The finding of her study revealed that dividend policy does not affect the increase of corporate value. Moreover, the study conducted by Mmbone et, al., (2015), which examine the relationship between voluntary disclosure and financial performance of companies quoted at the Nairobi securities exchange (NSE). In the study an annual reports of 10 listed companies in Nairobi Security Exchange was used to obtain a secondary data from 2011 to 2013 and the data set was regressed using Excel 2007. Their findings revealed a positive and significant relationship between the disclosure and corporate performance. They relate that organizations are reporting their financial activities not only on the count of attracting lower cost of capital but to attract the potential investors and creditors to invest for the maximization of corporate value.

\subsection{Financial Disclosure Vs Corporate Value}

The users of the disclosed financial information vary so as the nature of the information extracts from the report differs as well. For example, in most cases the potential and existing investors are paying much attention to the profitability ratio which demonstrates shareholders value (Mmbone,et, al., 2015). Thus, it can be understood that there is an existence of direct and or indirect connection between the financial disclosure and corporate value (Naser, 1995 and Hossain; Perera \& Rahman, 1995). Therefore, the structure of capital maintained by the organization in most cases used to affect the financing decision which is usually drawn after considering the available financial information disclosed by the firm (Mmbone,et, al., 2015). Similarly, Klapper \& Love (2002) and Barron, Kile \& O'Keefe (1999) have lamented that financial disclosure used to enhance historical analyses and encourage potential investors to improve their capabilities of planning and evaluating level of earnings in the long-run through sound and appropriate earnings forecasts. Worthington \& Tracey (2004) discussed that the financial information disclosed by the firms can be used by the stakeholders of the firm and other interested users to efficiently and effectively predict the future performance of the firm. Financial information disclosure leads to reduction of cost of capital to the company and eliminate information asymmetry (Ross, 1997).

In their individual studies, Belkaoui \& Kahl (1978) and Cooke (1989) opined that companies most disclose their incurred financial and non financial obligations (both short and long terms), since it is the yard-stick used by investors and other lenders to estimate the level of risk before they decide to invest or otherwise. Even though, firm with lower liquidity tend to disclose more financial information in order to explain their status (Wallace, Naser \& Mora, 1994). Financial statement disclosed by a firm improves its performances through various economic ways including maximization of shareholders value (Worthington \& Tracey, 2004).

Previously, a large number of empirical studies have found different types of connection between the financial disclosure and corporate value. For example, some studies have found positive and significant effects of financial disclosure against the corporate value (see, Mmbone, et, al., 2015; Kristandle \& Bontis, 2007; Leuz \& Verrechia, 2000; Ross, 1997; Wallace \& Naser,1995; Hossain, et al., 1995), negative effects (see, Efni, 2017).

H1: Financial disclosure has a positive and significant effect on the corporate value of the Jordanian listed industrial firms.

\subsection{Dividend Policy Vs Corporate value}

Dividend policy has been described as a guidelines to the management of the firm through which the managers determine the proportion of the profits to be shared to the respective shareholders as a cash return of their individual investments as well as the portion to be retained for future investment by the firm (Khan \& Ramirez, 1993) and a rule that guides managers in distributing rewards to the owners of investments (Nissim \& Ziv, 2001). Therefore, Mvuba, et, al., (2015) argued that dividend policy could either be residual policy of stable policy. Thus, a firm is said to be using residual policy, when the firm heavily funded its profitable investments with retaining earnings (Aduda \& Kimathi, 2011) and stable dividend policy, when the company is committed to an uninterrupted instalmental payments of cash dividend irrespective of profit's fluctuations ((ApGwilym, et, al., 2000). The strategy of distributing cash dividend to the shareholders in the current period will successively lead to an increase of firm performance in the subsequent financial year (Arnott \& Asness, 2003).

In many instances, various researchers have believed that a direct and or indirect relationship have existed between the dividend policy and financial disclosure. As such, Lin, Kuo \& Wang (2016) argued that a firm with lower disclosure should pay higher rate of dividend in order to create reputation for good shareholders treatments. They concluded that disclosure quality had negative effects on the dividend payout.

Similarly, Adams and Mehran (2005) defined financial performance as the end result of primary utilization of firm assets to generate proceeds during ordinary business operations. Financial performance can also be used as a general measure of a firm overall financial level over particular time duration and can be used for comparison of general performance of different firms operating in the same industry. In general, financial performance is a gauge to express the general financial productivity of an organization over a span of financial period and aids in comparison of financial results of other firms in the same sector. Investors recognize the 
potentials of a company, both current and future, through its market valuation. Thus, they always expect managers to increase the market value of the firm in anticipation of high returns on their investments. This is because a rise in the market value of a company's shares is considered an increase in wealth for the company. Poor growth prospects adversely affect firm value; therefore, an effective performance measure is one that reflects the extent of the growth (Gikonyo, 2008).

Accordingly, several literature have empirically evidenced the relationships or otherwise between the dividend policy and corporate value. Hence, this could be traced from the work of Modigliani \& Miller (9061), where they argued that ability of a firm to create more earnings is relatively linked to its value and financial performance whereas, dividend policy has no effects on the determination of corporate performance. Contrarily, in the agency theory Jesen \& Merckling (1976) described the association between financial performance of a firm and dividend policy, where they highlighted the linkage of interest between the managers and shareholders. Al-kuwari (2009) claimed that both existing and potential investors have considered dividend policy as a source of information which communicates the future financial viability of a firm. Moreover, several studies have individually revealed a positive and significant relationship between dividend policy and corporate value (see for example, Kajola, et, al., 2015; Dogan \&Topall, 2014; Uwuigbe, 2013; Murekefu \& Ouma, 2012). While, an indirect relationship was established in some studies (see the work of Maladjian \& El Khoury, 2014).

In the empirical study conducted by Dogan \& Topal (2014), in which they investigated the linkage between the dividend policy and corporate value in the listed firms at the stock exchange of Istanbul. Their data set was collected from the annual reports of 172 non financial firms covering the period of 4 years from 2008 to 2011 . They categorized the selected firms into two different groups as firms that paid dividend regularly paid and firms that paid dividend based on trends (irregular). The study examined the possibility of getting significant relationship between the financial performance and accounting towards the impacts of dividend policy in the aforementioned defined groups. Accordingly, they employed descriptive statistical tools, multiple regression and t-test to analyse the results. Their findings revealed that dividend payout has a positive impact on the corporate value. Moreover, Murekefu \& Ouma (2012) imperially grilled the correlation that exists between dividend payout and firm performance of the listed companies at the securities exchange of Nairobi. A secondary data was extracted from the annual financial statements published by the selected Nairobi listed firms for the period of 9 years (2002 to 2010). They used multiple regressions to analyse the data set and their findings established that there is direct influence between dividend payout and financial performance in the Nairobi listed firms. These finding were in line with the result of Arnott \& Asness (2003). The proposed that both existing and potential shareholders used to be attracted by the amount of cash dividend paid by the firm.

H2: Dividend policy has positive and significant effects on the corporate value of the Jordanian listed industrial firms.

H3: Dividend policy has positively and significantly moderates the effects of financial disclosure on the corporate value of the Jordanian listed industrial firms.

\subsection{Research Methodology}

In this study, descriptive research design is employed due to the fact that, the study encompasses collecting, analysing, organizing, tabulating and describing the data obtained. Therefore, the study contains three types of variables, such as dividend policy as the moderating variable, financial disclosure as an independent variable and lastly corporate value as a dependent variable. As adopted from previous researches, the moderating variable (dividend policy) is measured by three indicators comprising Dividend Pay-out Ratio (DPR), Dividend Yield (DY) and Earning per Share(EPS) (see, Mbuva, etal, 2017; Kajola, et, al., 2015; Maladjian \& El Khoury, 2014; Uwuigbe, 2013), while the independent variable (Financial Disclosure) has been measured by four indicators such as Liquidity Ratio (LR), Acid Test Ratio (ATR), Debt to Equity Ratio (DER) and Gearing Ratio (GR) (Mmbone, et, al., 2015) and the dependent variable (corporate value) was measured by four indicators as Economic Value Added (EVA), Return on Equity (RoE), Return on Investment (RoI), Return on Asset (RoA) (see, Mmbone, et, al., 2015; Al-Malkawi, 2007).

Moreover, the population of this study were a total number of 96 industrial firms listed in ASE as in the study of Muhammad, et. al. (2011). Therefore, a total of 61 industries were selected as samples for analysis using purposive technique. Additionally, the data set has been extracted from the audited annual financial reports of the sampled Jordanian industrial firms for the period of 13 years (2005 to 2017) based on the following consideration:

i. That the selected firms have been listed in ASE throughout the period under review (2005 to 2017) and have never been unlisted for once.

ii. That the selected firms have made their audited financial reports available online either on their website or on the portal of ASE covering the period under review.

iii. That the firms used as a sample of this study has made a full disclosure of their financial activities and duly audited and certified by external auditor. 
iv. That the annual reports of the firms are up to date covering the period of 13 years (2005 to 2017). Accordingly, the extracted data on the variables (i.e dividend policy, financial disclosure and corporate value) was critically analysed and the related effects between the variables were regressed structurally using SmartPLS version 3 .

\subsection{Description of Indicators}

Table 1: Indicators for Measuring the Variables

\begin{tabular}{|c|c|c|c|c|}
\hline Variables & Description & Indicators & Sources & $\begin{array}{l}\text { Expected } \\
\text { Outcomes }\end{array}$ \\
\hline $\begin{array}{c}\text { FINANCIAL } \\
\text { DISCLOSURE }\end{array}$ & $\begin{array}{l}\text { Dependent } \\
\text { Variable }\end{array}$ & $\begin{array}{c}\text { Liquidity Ratio (LR), } \\
\text { Acid Test Ratio } \\
\text { (ATR), Debt/Equity } \\
\text { Ratio (DER) and } \\
\text { Gearing Ratio (GR) }\end{array}$ & Mmbone, et, al., (2015) & + \\
\hline $\begin{array}{c}\text { CORPORATE } \\
\text { VALUE }\end{array}$ & $\begin{array}{c}\text { Independent } \\
\text { Variable }\end{array}$ & $\begin{array}{c}\text { Return on Equity } \\
\text { (RoE), Return on } \\
\text { Investment (RoI), } \\
\text { Return on Asset RoA) } \\
\text { and Economic Value } \\
\text { Added (EVA) }\end{array}$ & $\begin{array}{l}\text { Mmbone, et, al., (2015), } \\
\text { Dogan and Topal (2014), } \\
\text { Al-Malkawi (2007). }\end{array}$ & + \\
\hline $\begin{array}{c}\text { DEVIDEND } \\
\text { POLICY }\end{array}$ & Moderator & $\begin{array}{c}\text { Dividend Pay-out } \\
\text { Ratio, Dividend Yield } \\
\text { and Earning per Share. }\end{array}$ & $\begin{array}{c}\text { Mbuva, et. al., (2017), } \\
\text { Kajola, Adewumi \& Oworu } \\
\text { (2015), Maladjian \& El } \\
\text { Khoury (2014), Uwuigbe } \\
\text { (2013). }\end{array}$ & $+/-$ \\
\hline
\end{tabular}

Source: Designed by the Researcher, 2018

4.0 DATA PRESENTATION AND ANALYSIS

4.1 RESULT OF CONSISTENT PLS ALGORITHM

Table 2: Results Summary for Reflective Outer Models

\begin{tabular}{|c|c|c|c|c|c|}
\hline $\begin{array}{c}\text { Latent } \\
\text { Variables }\end{array}$ & Indicators & Loadings & $\begin{array}{c}\text { Indicators Reliability } \\
\left(\text { Loadings }^{2}\right)\end{array}$ & $\begin{array}{l}\text { Composite } \\
\text { Reliability }\end{array}$ & AVE \\
\hline \multirow{4}{*}{$\begin{array}{c}\text { Corporate } \\
\text { Value }\end{array}$} & EVA & 0.763 & 0.582 & \multirow{4}{*}{0.894} & \multirow{4}{*}{0.680} \\
\hline & RoA & 0.892 & 0.796 & & \\
\hline & RoE & 0.835 & 0.697 & & \\
\hline & RoI & 0.802 & 0.643 & & \\
\hline \multirow{3}{*}{$\begin{array}{c}\text { Dividend } \\
\text { Policy }\end{array}$} & DPR & 0.775 & 0.601 & \multirow{3}{*}{0.734} & \multirow{3}{*}{0.624} \\
\hline & EPR & 0.718 & 0.516 & & \\
\hline & DY & 0.677 & 0.458 & & \\
\hline \multirow{4}{*}{$\begin{array}{c}\text { Financial } \\
\text { Disclosure }\end{array}$} & ATR & 0.838 & 0.702 & \multirow{4}{*}{0.876} & \multirow{4}{*}{0.641} \\
\hline & DER & 0.875 & 0.766 & & \\
\hline & GR & 0.769 & 0.591 & & \\
\hline & LR & 0.710 & 0.504 & & \\
\hline $\begin{array}{l}\text { Moderating } \\
\text { Effects }\end{array}$ & $\begin{array}{c}\text { FINANCIAL } \\
\text { DISLOSURE*DIVIDEND } \\
\text { POLICY }\end{array}$ & 1.000 & 1.000 & 1.000 & 1.000 \\
\hline
\end{tabular}

Source: Default Report of Analysed Data via SmartPls 3

Hulland, (1999) relates that in order to establish indicator reliability the value of indicators loadings should be squired thus, the value obtained must be at least minimum of 0.4 and preparedly the value should be 0.7 . Consequently, table 2 above, depicted the indicator reliability of the individual measurements, in which all indicators used were having a value larger than the minimum required value (0.4) (i.e EVA, RoE, RoI, DPR, EPR, DY, GR and LR) whereas, some of the indicators were having value greater than the prepared value $(0.7)$ (i.e RoA, ATR and DER).

Additionally, Bagozzi \& Yi (1988) and Hair et al., (2012) have suggested the use of composite reliability as the best approach of measuring internal consistency reliability of the indicators and it should be 0.7 or higher. Hence, it can be glanced from the table 1 above, that the composite reliability value of individual reflective indicators are larger than the quoted value of 0.7 as such it can be concludes that the internal consistency reliability is achieved. Moreover, the Average Variance Extracted (AVE) of each latent variable is evaluated, 
where it was shown in the table 1 above, that the individual latent constructs has AVE value larger than the acceptable 0.5 value suggested Bagozzi \& Yi (1988) for the attainment of accepted convergent validity in the model.

\subsubsection{DISCRIMINANT VALIDITY}

To check the discriminant validity of the latent constructs, Fornell \& Larcker (1981) recommend that the square root of Average Variance Extracts (AVE) in the latent constructs should be identified and ensures that their values have overweight the other correlated values amongst the latent variables. Therefore, the table 2 below had shown the values of AVEs' squire roots which were diagonally written in bold and the correlation of the latent constructs were also placed in a triangle form at the lower left of the table.

Table 3: Fornell \& Larcker Criterion Analysis for Checking Discriminant Validity

\begin{tabular}{|c|c|c|c|c|}
\hline CONSTRUCTS & $\begin{array}{c}\text { CORPORATE } \\
\text { VALUE }\end{array}$ & $\begin{array}{c}\text { DIVIDEND } \\
\text { POLICY }\end{array}$ & $\begin{array}{c}\text { FINANCIAL } \\
\text { DISCLOSURE }\end{array}$ & Moderating Effect \\
\hline CORPORATE VALUE & $\mathbf{0 . 8 2 5}$ & & & \\
\hline DIVIDEND POLICY & 0.787 & $\mathbf{0 . 7 9 0}$ & & \\
\hline FINANCIAL DISCLOSURE & 0.810 & 0.726 & $\mathbf{0 . 8 0 0}$ & \\
\hline Moderating Effect & -0.042 & 0.035 & -0.083 & $\mathbf{1 . 0 0 0}$ \\
\hline
\end{tabular}

Source: Default Report of Analysed Data via SmartPls 3

It can be established from the table 1 that the AVE value of dividend policy is 0.624 , in which its squire root was found to be 0.790 as in the table 2 . Therefore, this value $(0.790)$ is higher than the value of the correlation in the column of dividend policy $(0.726$ and 0.035$)$ as well as larger than the value dividend policy in the row (0.787). Accordingly, the same observation is applied to the rest of the latent variables in the model (FINANCIAL DISCLOSURE, CORPORATE VALUE AND MODERATING EFFECT). Finally, the result proved that there is no issue of discriminant validity between the latent constructs. Moreover, in this study the indicators were free from collinearity issues since the separate VIF value is achieved at tolerance level lower than 5 as suggested Hair et al., (2011).

Figure 1: Consistent PLS Algorithm-Regression Path Coefficients

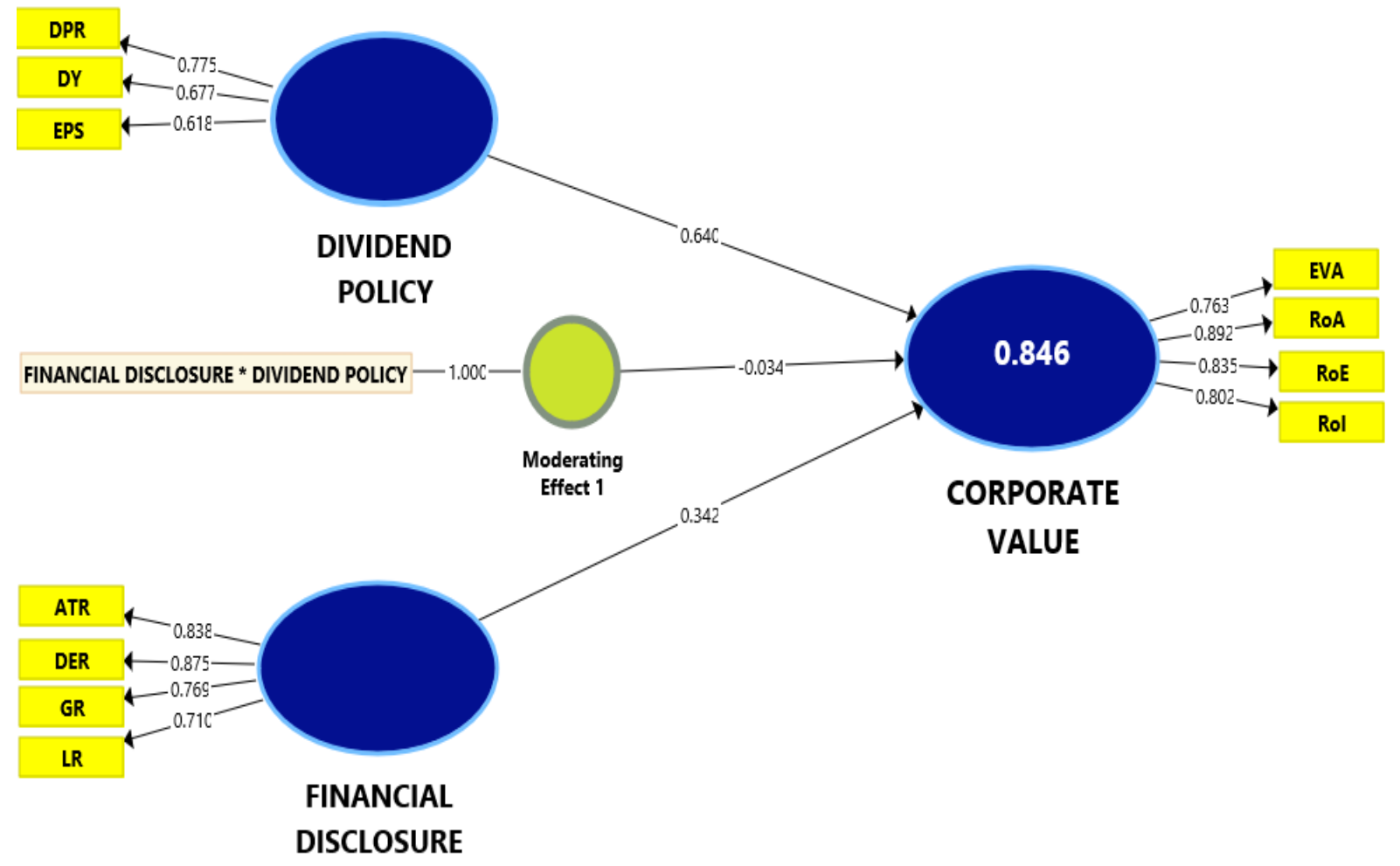

Source: Default Report of Analysed Data via SmartPls 3

Accordingly, the figure 1 above presents the diagrammatical result of consistent PLS algorithm-regression path coefficients including the $\mathrm{R}^{2}$ value which shows the extent at which the independent latent variable contributes toward predicting the depended variable. Therefore, the exogenous variables have contributed with 0.846 equivalents to $85 \%$ in the prediction of endogenous latent variable. 
4.2 RESULTS OF CONSISTENT BOOSTRAPPING

Table 4: T-Statistics of Path Coefficients (Inner Model)

\begin{tabular}{|l|c|}
\hline & $\begin{array}{c}\text { T Statistics } \\
(\mid \mathbf{O} / \text { STDEV } \mid)\end{array}$ \\
\hline DIVIDEND POLICY -> CORPORATE VALUE & 12.413 \\
\hline FINANCIAL DISCLOSURE -> CORPORATE VALUE & 6.561 \\
\hline Moderating Effect 1 -> CORPORATE VALUE & 2.217 \\
\hline
\end{tabular}

Source: Default Report of Analysed Data via SmartPls 3

Table 5: T-Statistics (|O/STDEV|) of Path Coefficients (Outer Model)

\begin{tabular}{|l|c|c|c|}
\hline & $\begin{array}{c}\text { Financial } \\
\text { Disclosure }\end{array}$ & $\begin{array}{c}\text { Corporate } \\
\text { Value }\end{array}$ & Dividend Policy \\
\hline Assets to Revenue (ATR) & $\mathbf{4 0 . 6 5 1}$ & & \\
\hline Debt to Equity Ratio (DER) & $\mathbf{4 1 . 0 0 3}$ & & \\
\hline Gearing Ratio (GR) & $\mathbf{3 5 . 8 3 8}$ & & \\
\hline Liquidity Ratio (LR) & $\mathbf{2 8 . 0 3 4}$ & & \\
\hline Return on Assets (RoA) & & $\mathbf{4 3 . 8 0 6}$ & \\
\hline Return on Equity (RoE) & & $\mathbf{5 2 . 6 7 1}$ & \\
\hline Return on Investment (RoI) & & $\mathbf{5 2 . 1 4 6}$ & \\
\hline Economic Value Average (EVA) & & $\mathbf{5 2 . 1 4 6}$ & \\
\hline Dividend Per Share (DPR) & & & $\mathbf{2 6 . 8 9 2}$ \\
\hline Dividend Yield (DY) & & & $\mathbf{2 8 . 7 0 5}$ \\
\hline Earnings Per Share (EPS) & & & \\
\hline \multicolumn{2}{|l}{} & & \\
\hline
\end{tabular}

Source: Default Report of Analysed Data via SmartPls 3

Table 4 above have shown the individual value of T-Statistics of the indicators, whereas the values of the Tstatistics in the outer model are larger than suggested minimum required value as 1.96 . As such, it can be concluded that the loadings of the outer model are highly significant.

Table 6: Testing of Research Hypotheses-Regression Weight Coefficient

\begin{tabular}{|l|c|c|c|c|}
\hline Latent Variables & Estimate & $\begin{array}{c}\text { T Statistics } \\
(\mid \text { O/STDEV } \mid)\end{array}$ & P Value & Result \\
\hline Dividend Policy $\longrightarrow$ Corporate Value & $\mathbf{0 . 6 4 0}$ & $\mathbf{1 2 . 4 1 3}$ & $\mathbf{0 . 0 0 0}$ & Significant \\
\hline Financial Disclosure $\longrightarrow$ Corporate Value & $\mathbf{0 . 3 4 2}$ & $\mathbf{6 . 5 6 1}$ & $\mathbf{0 . 0 0 0}$ & Significant \\
\hline Moderating Effect $1 \longrightarrow$ Corporate Value & $\mathbf{- 0 . 0 3 4}$ & $\mathbf{2 . 2 1 7}$ & $\mathbf{0 . 2 2 4}$ & Insignificant \\
\hline
\end{tabular}

Source: Default Report of Analysed Data via SmartPls 3

In this study, it is found that DPR, DY and EPS are part of the integral elements to be considered by an organization in the formulation/determination of dividend policy. Considering their loadings $0.775,0.718$ and 0.677 respectively (see table 2) it indicates that they are perfect indicators of dividend policy. Therefore, managers of the Jordanian industrial firms are expected to give much concern over the indicators since they have significantly affected the dividend policy. Thus, the regression coefficient (see table 6) indicated that when dividend policy goes up by 0.0642 the corporate value will increase by 1 at p-value less than 0.001 (two tailed). Likewise, the regression analysis revealed that the indicators used in measuring the latent variable (financial disclosure) where proved to be significant and positively contribute towards the determination of the financial disclosure in an organization. Hence, the factor loadings of the individual indicators were depicted as 0.838 , $0.875,0.769$ and 0.710 for ATR, DER, GR and LR correspondingly (See, table 2). Moreover, the regression coefficient designated that corporate value goes up by 1 when the coefficient of financial disclosure goes up by 0.342 as such the T-statistics of the inner model is 6.561 at a p-value lower than 0.001 (two tailed). Accordingly, the factor loadings of the indicators used to measure corporate values as shown in the table 5 were significantly positive since they have values higher than 0.6 . the values of the indicators were presented as $0.763,0.892,0.835$ and 0.802 for EVA, RoA, RoE and RoI respectively (See, table 2). Based on the results of the indicators factor loadings (See, table 2) it is finally proved that the reflective measures used in measuring the latent variables were significantly and positively important in measuring the latent variables under study.

Additionally, from the table 6 above, it can be seen that the regression path coefficient of the moderating effects is -0.034 , which means that when corporate value goes up by 1 the moderating effects will goes down by -0.034 at p-value higher than 0.05 (two tailed). In other word, the moderating effect is insignificant. This indicated that dividend policy does not moderate the effects of financial disclosure on corporate value in the Jordanian industrial firm. 


\subsection{DISCUSSION OF FINDINGS}

Considering the previous discussions in respect of the analysed data and the results of the hypotheses test from the regression path as indicated in table 6 above, thus, the hypothesis 1 which states that there is a positive and significant effect between financial disclosure and corporate performance in the Jordanian listed industrial firm is accepted at significant level $<0.001$ (two tailed). Consequently, this finding concurred with results of (Mmbone,et, al., 2015; Kristandle \& Bontis, 2007; Leuz \& Verrechia, 2000). More so, the result illustrated that, once the Jordanian listed industrial firms increase the level of true and fair view disclosure of their financial transaction to the public, the corporate value of their firms will automatically go up since their disclosure will attracts the interest of various potential investors and creditors to subscribes their shares and debentures which will lead to an increase in the industrial working capital as well as profitability. For this reason, Mmbone, et. Al., (2015) relate in their examples that both potential and existing investors are considering the liquidity, gearing ratio and shareholders' value before they invest. As such, a firm that has low liquidity might disclose more information to explain their status, where the organizational information on budget and performances will be released in the disclosed financial results (Wallace, Naser and Mora, 1994).

Relatively, the findings of this study proved the acceptance of hypothesis 2, which states that dividend policy has positive and significant effects on the corporate value of the Jordanian listed industrial firm. As presented in table 6 above, the second hypothesis is accepted at significant p-value $>0.001$ (two tailed).Therefore, this result is attuned with individual findings of Kajola et al., (2015); Dogan \& Topall (2014); Uwuigbe (2013); Murekefu \& Ouma (2012). Accordingly, this finding has reaffirmed the view of Jensen \& Meckling (1976) in the agency theory where it revealed the harmonisation of interest between the managers and shareholders. Thus, the finding contradicted the theory of irrelevance coined by Modigliani \& Miller (1961), in which they opined that dividend policy has no role to play in whatever means towards determination of the corporate value. Despite, the M \& M theory of irrelevance, Leah (2008) confirmed that the value of an organization relies on the strategies, policies and monetary operations employed which reflects in the shareholders return. Additionally, Kajola, et, al., (2015) revealed in their findings that the portion of dividend paid by the firm is directly affecting the value of that firm.

Subsequently, the finding of this study have proved that the hypothesis 3, which states that dividend policy has positively and significantly moderate the effect of financial disclosure on the corporate value of the Jordanian listed industrial firms is rejected. The finding is corresponds with results of the previous studies conducted by Lin, et. al., (2016) and Chae, et, al. (2009). The finding has expressed in table 6 above, that dividend policy has insignificant moderating effects on the relationship between financial disclosure and corporate value of the listed Jordanian industries at p-value less than 0.05 (two tailed). Therefore, dividend policy can only contribute towards determination of the corporate value but has negative impact on the increase or decrease in the direction of financial disclosure over corporate value. According to Mbone, et, al. (2015), the current and future potentiality of a firm is recognised through markets valuation, where the shareholders expects managers to always increase the value of the company by paying higher return on investments. Therefore, the efficient performance measure of a firm is mostly reflects the growth of the firm, which is obtainable from the disclosure (Gikonyo, 2008).

\subsection{CONTRIBUTIONS AND SUGGESTION FOR FUTURE RESEARCH}

This study has contributed on the way to encouraging both Jordanian listed and unlisted industrial firms towards understanding the effects of financial disclosure on the corporate value in which higher quality financial disclosure leads to the increase in corporate value and reputation. Accordingly, the study provides the Jordanian managers, investors and other potential creditors alike with efficient knowledge on the reliable indicators to be considered in the process of making crucial financial and investment decisions. Moreover, this study will enhance those Jordanian industrial firms that are not disclosing their annual financial report to be divulging it; due to the facts that this study has uncovered that financial disclosure has significant and positive effects on the corporate value. And as such financial disclosure may not only illustrate transparency and accountability that shows financial security to the investors but it lead to minimization of cost of capital as well. Lastly, the study has immensely contributes toward bridging the gap in the existing field of knowledge specifically in Jordan, where study of this nature are very minimal.

This study had twigged to only examine the moderating effects of dividend policy on the effects of financial disclosure against the corporate value in the Jordanian listed industrial firms, as such it is suggested that a further research has to be conducted to determine the moderating or mediating effects of dividend policy on the relationship between various variables such as disclosure quality, corporate social responsibility disclosure, etc. and corporate value in another Jordanian economic sectors.

\section{CONCLUSION}

The role of financial disclosure towards increasing the level of transparency and accountability in the global 
business organization cannot be over emphasised. As such, in the view of various scholars, this may led to the increase of investments since both potential and existing investors as well as creditors are normally interested in gaining much return after maximising security of their injected funds. Thus, firms disclose its financial position including the distributable income in the prepared annual financial statement, which offers detail knowledge to the organizational managers towards formulating effective dividend policy. The dividend paid is another key factor considered by the investors, which highlights the possibility of earning desired return on investment and to some extent regarded as prerequisite element of determining the corporate value. consequently, over the decades, several studies have been proved the irrelevant role of dividend policy against the determination of the organizational value, for example the work of M\&M (1961) even though in after some years several findings were established contrary to theirs. For instance, Gordon, (1959) and Lintner (1956) have individually relates in their studies that dividend policy is one of the key determinant of corporate value.

Therefore, this study was conducted to find out whether the dividend policy has a moderating effect on the impact of financial disclosure over the corporate value in the Jordanian listed industrial firms. Hence, the result of this study revealed that financial disclosure and dividend policy have significant and positive effect on the corporate value in the Jordanian industrial firms at P-value $<0.001$ (two tailed) whereas the moderating effect of the dividend policy on the impact of financial disclosure over the corporate value is insignificant at $p$-value $>$ 0.05 (two tailed). Moreover, the $\boldsymbol{R}^{2}$ of the model is 84.6 which means the total contribution of the independent toward predicting the dependent variable is $85 \%$.

\section{RECOMMENDATIONS}

In considering the findings of this study the following recommendations were offered based on the aforementioned objectives of the study:

i. Disclosure of any kind, specifically financial disclosure in organizations both private and public is clearly indicating the existence of transparency and accountability in the organisation which proves financial security. As such, the Jordanian listed industrial firms are advice to consider a full disclosure of their financial transaction since accountability and transparency attracts potential investors and creditors alike to pick interest in doing business with utmost financial security.

ii. It is recommended that the Jordanian listed industrial firms should be given a maximum consideration to the indicators used in this study as a measurement of financial disclosure, dividend policy and corporate value since based on the findings it proves that the indicators were perfects to measure the employed variables. Therefore, placing much priority on them may efficiently equip the Jordanian industrial managers and investors with all necessary knowledge to make a sound and effective decision making makings especially in the areas of investment and financial decision as well as formulation of effective dividend policy.

\section{ACKNOWLEDGEMENT}

This research was funded by Deanship of Research in Zarqa University. I would like to Acknowledge Zarqa University who provided insight and expertise that greatly assisted the research.

\section{REFERENCES}

Adams, R. B. \& Mehran, H. (2005). Corporate performance, board structure and its determinants in the banking industry, in EFA, Moscow meetings.

Aduda, J. O. \& Kimathi, H. (2011). The Applicability of the constant dividend model for companies listed at the Nairobi stock exchange, Journal of Financial Studies \& Research, pp. 1-38.

Ahmed, H. \& Javid, A. Y. (2009). Dynamics and determinants of dividend policy in Pakistan: evidence from Karachi stock exchange non- financial listed firms. Journal of Finance and Economics, 25(1), 148-171.

Al-Habaybah, K. (2009). "Factors influencing the extent of mandatory compliance with IAS disclosure requirements by manufacturing companies listed at Amman Stock Exchange" unpublished dissertation, the Arab academy for banking and financial sciences, Amman, Jordan.

Ali, K. L., Khan, A. Q. \& Ramirez, G. G. (1993). Determinants of corporate dividend policy: A factorial analysis, Financial Review, 4(28), 523-547.

Al-Kuwari, D. (2009). Determinants of the dividend payout ratio of companies listed on emerging stock exchanges: The case of the Gulf Cooperation Council (GCC) countries. Global Economy \& Finance Journal, 2(2), 38-63.

Al-Malkawi, H. (2007). Determinants of corporate dividend policy in Jordan: An application of the Tobit Model, Journal of Economics and Administrative Sciences, 23(2), 44-70.

Ap Gwilym, O., Morgan, G. \& Thomas, S. (2000). Dividend stability, dividend yield and stock returns: UK evidence. Journal of Business Finance and Accounting, 27(3), 261-281.

Arnott, R. \& Asness, C. (2003). Surprise! Higher dividends = higher earnings growth. Financial Analysts 
Journal, 59(1), 70-87.

Barako, D. G. (2007). Determinants of voluntary disclosure in Kenyan companies annual reports. African Journal of Business Management, 1(5), 113-128.

Barclay, M.J., Holderness, C.G., \& Sheehan, D.P. (2009). Dividends and corporate shareholders. Review of Financial Studies, 22 (6), 2423-2455. http://dx.doi.org/10.1093/rfs/hhn060

Barron, O.E., Kile, C.O., and O'Keefe, T. B. (1999). "MD \& A Quality as a Measure by the SEC and Analysts"e Earnings Forecasts." Contemporary Accounting Research 16 (Spring): 75-109.

Belkaoui-Riahi, A., and Kahl, A. (1978). Corporate financial disclosure in Canada. Vancouver: research monograph of the Canadian Certified General Accountants Association.

Black, B. (2000). The Core Institutions that Support Strong Securities Markets. Business Lawyer 55: 1565-1607.

Black, F. (1976). The dividend puzzle. Journal of Portfolio Management,2, 5 8.http://dx.doi.org/10.3905/jpm.1976.408558

Boesso, G., \& Kumar, K. (2007). Drivers of corporate voluntary disclosure: A framework and empirical evidence from Italy and the United States. Accounting, Auditing and Accountability Journal, 20(2), $269-296$.

Cooke, T. E. (1989). Voluntary corporate disclosure by Swedish companies. Journal of International Financial Management and Accounting, 1(2), 171-195.

Dogan, M. \& Topal, Y. (2014). The influence of dividend payments on company performance: The Case of Istanbul Stock Exchange (BIST). European Journal of Business and Management, 3(6), 189-197.

Gikonyo, J. W. (2008). EVA and market returns: The case of companies quoted on the NSE. Unpublished MBA project, University of Nairobi.

Yaseen, H., Omet, G. \& Abu-Khalaf, W. (2015). Dividend Policy of Jordanian Firms: Stability Tests and Survey Results International Business Research Canadian Center of Science and Education; Vol. 8, No. 8 pg 19139004

Hossain, M., Perera, M. H. B., \& Rahman, A. R. (1995). Voluntary disclosure in the annual reports of New Zealand companies. International Journal of Finance and Management Accounting. 6(1): 69-87.

Kajola, S. O., Adewumi, A. A. \& Oworu, O. O. (2015). Dividend pay-out policy and firm financial performance: evidence from Nigerian listed non-financial firms. International Journal of Economics, Commerce and Management, 3(4), 1-12.

khaleed, A. (2012). Accounting Disclosure In The Financial Reports In The Public Contribution Companies In The Presence Of International Accounting Standard (1), Damascus university journal.

Klapper, L. \& Love. I. (2002). Corporate governance, investor protection, and performance in emerging markets. Washington, DC. United States: World Bank. Mimeographed document.

Kristandl, G. \& Bontis, N. (2007). The impact of voluntary disclosure on cost of equity capital estimates in a temporal setting. Journal of intellectual capital 8(4), 577-594.

Leuz, C., and Verrecchia, R. E. (2000). The Economic Consequences of Increased Disclosure. Journal of Accounting Research, 38, 91-124.

Maladjian, C. \& El Khoury, R. (2014). Determinants of the dividend policy: An empirical study on the Lebanese listed banks. International Journal of Economics \& Finance, 4(6), 240-252.

Maniagi, G. M., Denco, M. J., Ondiek, B. A., Okaka, D. \& Musiega, D. (2013). Corporate governance, dividend policy and performance. Special reference to banks listed on Nairobi security exchange Kenya. International Journal of Innovative Research \& Development, 5(2), 56-69.

Maniagi, G. M., Denco, M. J., Ondiek, B. A., Okaka, D. \& Musiega, D. (2013). Corporate governance, dividend policy and performance. Special reference to banks listed on Nairobi security exchangeKenya. International Journal of Innovative Research \& Development, 5(2), 56-69.

Marsh, C. (2012). Financial Management for non-financial managers, Kogan Page.

Mbuva, G.K., Kaijage, E. \& Elly, D.O. (2017).Financial Performance and Dividend Policy, European Scientific Journal, Vol.13, No.28, pg 1857 - 7881

Miller, M., \& Modigliani, F. (1961). Dividend policy, growth, and the valuation of shares. Journal of Business. 34, 411-433.http://dx.doi.org/10.1086/294442

Mmbone, J.M, Hood, A.A \& Wambui, J.M. (2015). The Relationship between Voluntary Disclosure and Financial Performance of Companies Quoted At the Nairobi Securities Exchange. International Journal of Managerial Studies and Research (IJMSR) Volume 3, Issue 6, pg 2349-0349 (Online) www.arcjournals.org Page 171

Modigliani, F. \& Miller, M. (1961). Dividend policy, growth and the valuation of shares. The Journal of Business, 34(4), 411-428.

Mohammad, W.Y, Taher, S.A \& Jamil, A. A. (2011). The Effect of Corporate Governance on the Performance of Jordanian Industrial Companies: An empirical study on Amman Stock Exchange. International Journal of Humanities and Social Science Vol. 1 No. 4; pg55-69

Murekefu, T. M. \& Ouma, O. P. (2012). The relationship between dividend payout and firm performance: A 
study of listed companies in Kenya, European Scientific Journal, 8(9), 199-215.

Nissim, D. \& Ziv, A. (2001). Dividend changes and future profitability. The Journal of Finance, 56(6), 21112133.

Omran, M. \& Pointon, J. (2004). Dividend policy, trading characteristics and share prices: Empirical evidence from Egyptian firms, International Journal of Theoretical and Applied Finance, 7(2), 121-33.

Ross, S. A. (1997). The determinants of financial structure: the incentive signaling approach. Bell Journal of Economics and Management Science, 23-40.

Uwuigbe, O. R. (2013). An Examination of the effects of Ownership structure and financial leverage on the dividend policies of listed firms in Nigeria, Journal of Economics, Business and Accountancy Ventura, 2(16), $251-258$.

Wallace R. O., Naser K., and Mora, A. (1994). The relationship between the comprehensiveness of corporate annual reports and firm specific characteristics in Spain. Accounting Business Research. 25(97): 41-53.

Waweru, M. A. S. (2008). Competitive strategy implementation and its effect on performance in large private sector firms in Kenya, Unpublished PhD Thesis, University of Nairobi.

Worthington, A., and Tracey, W. (2004). A Review and Synthesis of the Economic Value-Added Literature. School of Economics and Finance. 